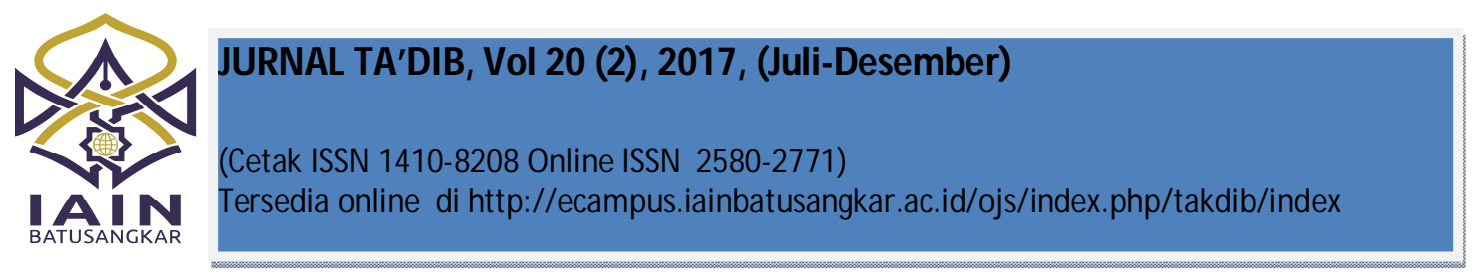

\title{
Development of Problem-Based Teaching Materials for The Fifth Graders of Primary School
}

\author{
Yanti Fitria *) \\ Program Studi Pendidikan Dasar, \\ Pacsasarjana Universitas Negeri Padang \\ E-mail: yantifitria@ymail.com atau \\ yanti_fitria@fip.unp.ac.id

\section{Idriyeni *} \\ Program Studi Pendidikan Dasar, \\ Pacsasarjana Universitas Negeri Padang \\ E-mail:-
}

\begin{abstract}
Due to the importance of attractive learning materials in achieving a qualified learning results, it needs to carry on the development of the materials. The aim of this research is to develop science teaching materials using problem-based-learning model for primary school students. The developed teaching materials should strengthen the students' knowledge and thinking skills. This research and development refers to Thiagarajan model, consisting of defining, designing, developing, and dessiminating stage. The defining stage is conducted to have curriculum analysis, needs analysis, concept analysis and student analysis. At the designing stage, the researchers design the teaching materials. At the next stage, the proposed teaching materials are tested in terms of validity and practicality through validation sheet and questionnaire response of teachers and students. At the dessiminating stage, the researchers conduct a limited-scale deployment to notify the effectiveness of teaching materials on the achievement of activities and student learning outcomes. As the result, it indicates that the problem-basedteaching materials obtain high validity, practicality, and effectiveness.
\end{abstract}

Key words: Learning materials, science learning, problem-based learning model.

\section{PENDAHULUAN}

Hakekat sains (Ilmu pengetahu-an alam, IPA) pada dasarnya merupakan cara mengetahui alam dan cara berpikir (way to know and way of thinking). Oleh karenanya pembelajaran IPA seharusnya mampu melibatkan siswa secara aktif dalam belajar, siswa harus dilibatkan dengan berbagai kegiatan nyata agar mereka memiliki konsep pengetahu-an yang relevan dengan yang dipelajarinya. Pembelajaran pada dasarnya merupakan proses interaksi dan komunikasi antara guru dan siswa, dimana guru sebagai pengajar dan siswa sebagai pembelajar. Selain itu siswa juga dituntut banyak bertanya dan harus bisa mengem-bangkan kemampuan berfikir dalam memecahkan suatu masalah, dengan kegiatan ini maka dengan sendirinya siswa terlatih untuk berfikir ilmiah. Hal ini sesuai dengan yang dijelaskan Samatowa (2006:5) bahwa dalam pembelajaran IPA ada beberapa aspek yang harus diperhatikan yakni :

(a) pentingnya memahami bahwa pada saat memulai pembela-jaran IPA siswa telah memiliki berbagai konsepsi, pengetahuan yang relevan dengan apa yang mereka pelajari, (b) aktivitas siswa melalui berbagai kegiatan nyata dengan alam menjadi hal utama dalam pembelajaran IPA, (c) dalam setiap pembelajaran IPA kegiatan bertanyalah yang menjadi bagian penting, bahkan menjadi bagian yang paling utama dalam pembelajaran, (d) dalam pembelajaran IPA memberikan kesempatan kepada siswa untuk mengembangkankemampuan berfikirnya dalam menjelaskan suatu masalah.

Proses pembelajaran IPA sangat ditentukan dari faktor guru. Guru harus mampu mengelola kelas dengan baik dan menciptakan aktivitas pembelajaran yang sesuai dengan pengembangan diri yaitu 
pengembangan pengetahuan, keterampilan dan sikap. Guru mampu menciptakan pembelajaran yang berfokus kepada interaksi antara siswa dengan obyek, dan peran guru hanyalah sebagai fasilitator. Guru perlu menciptakan kondisi pembelajaran yang menye-nangkan dan menyediakan sarana yang dibutuhkan siswa untuk mengamati alam. Sesuai dengan pendapat Asy'ari (2006:37) bahwa dalam pembelajaran sains yang menjadi fokus adalah adanya interaksi antara siswa dengan obyek atau alam secara langsung. Oleh karena itu guru sebagai fasilitator perlu menciptakan kondisi dan menyediakan sarana agar siswa dapat mengamati dan memahami obyek sains. Dengan demikian siswa dapat menemukan konsep dan memba-ngunnya dalam struktur kognitifnya.

Materi hubungan antara gaya, gerak, dan energi merupakan salah satu topik IPA yang diajarkan di kelas V SD. Analisis penulis terhadap Kurikulum Tingkat Satuan Pendidikan (KTSP) 2006 menemukan bahwa Standar Kompetensi (SK) yang berkaitan dengan materi tersebut adalah SK 5. yaitu memahami hubungan antara gaya, gerak, dan energi serta fungsinya.

Guru diharapkan dapat membimbing siswa dengan maksimal dalam proses pembelajaran mengingat pentingnya pembelajaran IPA, maka guru harus mampu memilih dan menyiapkan materi ajar sesuai prinsip pengembangannya agar siswa dapat mencapai kompe-tensi yang diharapkan. Materi ajar yang dikembangkan dapat diorgani-sasikan dalam bentuk bahan ajar.Kemampuan guru dalam mengem-bangkan bahan ajar terkait dengan kompetensi pedagogik dan kompetensi profesional seperti yang tercantum dalam lampiran Permen-diknas Nomor 16 Tahun 2007.

Bahan ajar merupakan seperang-kat materi pembelajaran yang disusun secara sistematis yang dapat digunakan untuk mendukung proses pembelajaran. Sesuai dengan penda-pat Prastowo (2013:16) bahan ajar merupakan segala bahan (baik informasi, alat, maupun teks) yang disusun secara sistematis, yang menampilkan sosok utuh dari kompetensi yang akan dikuasai oleh siswa dan digunakan dalam proses pembelajaran dengan tujuan perenca-naan dan penelaahan implementasi pembelajaran.

Bahan ajar yang baik seharusnya disusun oleh guru sesuai dengan kebutuhan dan karakteristik siswa. Bahan ajar merupakan informasi maupun alat yang diperlukan guru untuk perencanaan dan penelaahan implementasi pembelajaran. Bahan ajar biasanya berisi materi mata pelajaran yang akan dicapai oleh siswa. Menurut Majid (2007:173), bahwa bahan ajar adalah segala bentuk bahan yang digunakan untuk membantu guru dalam melaksanakan kegiatan belajar mengajar.

Menurut Sagala (2009:23) salah satu kompotensi profesionalisme yang harus dimiliki guru adalah mampu menyusun bahan ajar yang berkualitas dengan standar kompe-tensi, kompetensi dasar, dan sesuai dengan kebutuhan serta karakteristik siswa. Penyusunan bahan ajar yang sesuai dengan kebutuhan dan karakteristik siswa, akan dapat membantu guru dalam kegiatan belajar mengajar dan membantu siswa dalam proses belajar sehingga tujuan pembelajaran yang diinginkan dapat tercapai.

Siswa kelas V SD termasuk pada siswa kelas atas yang biasanya berada pada rentang usia 10-11 tahun. Menurut Piaget (dalam Asy' ari, 2006: 42) siswa kelas atas berada pada tingkat perkembangan akhir operasional kongkrit sampai pada tahap awal operasional formal.Pada tahap ini siswa berpikir dalam cara-cara yang abstrak dan lebih logis. Siswa senang belajar dalam kelompok, mengeluarkan pendapat, serta mampu menganalisis dan memecahkan masalah dengan cara melakukan penelitian atau pengujian. Berdasarkan karakteristrik tersebut, maka perlu disusun bahan ajar yang memberi kesempatan kepada siswa untuk melakukan penelitian dan pengujian, 
sehingga siswa dapat mencaritahu sendiri apa yang ingin diketahuinya.

Pentingnya penggunaan bahan ajar sangat menentukan proses pembelajaran bermutu, diharapkan guru dapat merancang dan menyusun bahan ajar dengan baik. Tetapi berdasarkan analisis yang penulis lakukan pada pembelajaran IPA di kelas V SD, terlihat bahwa guru biasanya mengajarkan setiap materi IPA hanya berpedoman pada buku teks dari penerbit, sehingga proses pembelajaran pun masih terpusat kepada guru (teacher centered).

Analisis terhadap buku teks yang digunakan di sekolah, menunjukkan bahwa pada bagian awal materi kadang tidak disertai dengan pemberian pertanyaanpertanyaan yang faktual, padahal pemberian pertanyaan-pertanyaan faktual dapat membantu membang-kitkan minat siswa terhadap materi yang akan dipelajari. Pada rancangan percobaan di buku teks ditemukan contoh rancangan percobaan yang dirancang dengan langkah-langkah atau petunjuk yang kurang jelas. Akibatnya, guru jarang mengajak siswa melaksanakan percobaan yang seharusnya dilaksanakan, sehingga siswa jarang mendapatkan kesempatan untuk mencari tahu sendiri apa yang ingin diketahuinya.

Buku teks terkadang juga tidak memberi ruang bagi siswa untuk mengkonstuksi sendiri penemuan konsep yang telah dipelajarinya terlebih dahulu, tetapi langsung memberikan penjelasan dalam bentuk uraian materi. Siswa pun banyak belajar dengan hanya mengandalkan hafalan materi tapi kurang mengetahui bagaimana cara menerapkan konsep yang dipelajari dalam konteks yang berbeda.Buku teks juga memberi kesempatan kepada siswa untuk melaksanakan evaluasi diri. Padahal evaluasi diri berguna untuk mengetahui kekurangan dan kemajuan siswa dalam pembelajaran.Hal ini pada akhirnya berakibat kepada hasil belajar siswa yang masih kurang dari tujuan yang diharapkan.
Data hasil belajar menunjukkan masih banyak siswa yang mendapat-kan nilai di bawah KKM yang telah ditetapkan. Persentase ketuntasan siswa secara klasikal juga belum sesuai dengan yang diharapkan. Sesuai dengan ketentuan Depdikbud (dalam Trianto, 2011:241) yang menyatakan bahwa ketuntasan klasikal dalam suatu kelas adalah apabila $\geq 85 \%$ siswa telah tuntas belajarnya. Hal ini menggambarkan bahwa pemahaman siswa dalam pembelajaran IPA perlu ditingkatkan.

Usaha yang dapat ditempuh untuk menyikapi persoalan ini adalah dengan merancang bahan ajar dengan menggunakan model pembe-lajaran yang sesuai. Menurut Trianto (2011:54) "setiap model pembelajar-an mengarahkan guru dalam mendi-sain pembelajaran untuk membantu siswa sedemikian rupa hingga tujuan pembelajaran tercapai”.

Model pembelajaran untuk pengembangan bahan ajar yang dapat menuntun siswa belajar secara aktif dan sesuai dengan permasa-lahan yang telah diuraikan adalah model Problem based Learning. Model Problem based Learning merupakan model pembelajaran dengan lima tahapan. Hal ini dijelaskan Rusman (2011:243) kelima tahapan adalah (1) orientasi siswa pada masalah, (2) mengorga-nisasikan siswa untuk belajar,(3) membimbing pengalam-an induvidu-al atau kelompok, mengembang-kan dan mengajukan hasil karya, dan (5) menganalisis dan mengevaluasi proses pembelajaran. Dengan melaksanakan kelima tahapan dari model Problem based Learning dapat membantu mengatasi masalah yang terjadi sehingga terciptalah pembelajaran yang membangkitkan minat dan rasa ingin tahu siswa, memberi kesempatan kepada siswa untuk melakukan percobaan, mendo-rong siswa menjelaskan konsep yang dipelajari, membantu siswa menerapkan konsep dalam situasi baru dan melaksanakan evaluasi diri untuk mengetahui kekurangan dan kemajuannya dalam pembelajaran. 
Pada akhirnya, pelaksanaan kelima tahapan model Problem based Learning tersebut diharapkan akan mampu mengembangkan sikap aktif pada diri siswa dalam proses pembelajaran. Ditinjau dari hal tersebut maka peneliti tertarik untuk membahas masalah dalam suatu Penelitian Pengembangan dengan judul Pengembangan Bahan Ajar IPA Berbasis Model Problem based Learning untuk Siswa Kelas V SD.

\section{METODE PENELITIAN}

\section{Jenis Penelitian}

Jenis penelitian ini adalah penelitianpengembangan (develop-ment research) mengacu pada model yang dikembangkaan Thiagarajan (1974). Penelitian pengembangan merupakan kegiatan pengumpulan, pengolahan, analisis, dan penyajian data yang dilakukan secara sistematis dan objektif. Pengembangan suatu produk untuk memecahkan suatu persoalan yang dihadapi. Metode penelitian yang digunakan untuk menghasilkan produk dan menguji keefektifan produk tersebut (Sugiyono, 2011:87).

\section{Waktu dan Tempat Penelitian}

Penelitian ini dilakukan di kelas V Madrasah Ibtidaiyah Negeri (MIN) Koto Luar semester dua pada tahun ajaran 2015/2016.

\section{Subjek Penelitian}

Subjek penelitian adalah siswa kelas $\mathrm{V}$ sebagai kelas uji coba produk pengembangan di Madrasah Ibtidaiyah Negeri (MIN) Koto Luar di Kota Padang.

\section{Prosedur Penelitian}

Prosedur penelitian pengembangan memuat tahap-tahap yang harus dilakukan dalam setiap pengembangan yang dilakukan. langkah 4-D pada materi gaya kelas V Sekolah Dasar. Model pengembangan adalah seperangkat prosedur yang berurutan untuk melaksanakan perancangan dan pengembangan pembelajaran yang diwujudkan dalam bentuk grafis (diagram) atau naratif. Model pengembangan menurut Thiagarajan, dkk terdiri atas empat tahap meliputi pendefinisian (Define), perancangan (Design), pengembangan (Develop) dan penyebaran (Disseminate). Akan tetapi ,karena keterbatasantenaga, biaya, baran (disseminate) hanya dilakukanpada skala terbatas yaitu kelas lain atau sekolah lain yang sesuai dengan kebutuhan peneliti. Kegiatan tahap define dilakukan dalam bentuk analisis kurikulum, analisis konsep, analisis bahan ajar yang tersedia, dan analisis karakteristik peserta didik. Kegiatan design adalah merancang bahan ajar berbasis masalah. Selanjutnya bahan ajar yang telah dirancang dilakukan uji validitas dari segi konstruk dan isi bahan ajar oleh pakar dan praktisi yang selajutnya diimplementasikan pada siswa kelas VA MIN Koto Luar untuk melihat praktikalitas bahan ajar (tahap develop). Tahap disseminate meliputi uji coba terbatas bahan ajar pada kelas VB melihat keefektifan bahan ajar yang dikembangkan menggunakan poor experimen disign (rancangan eksperimen sederhana dengan pengujian statistik secara deskriptif Fraenkel (2012)

\section{Instrumen}

Instrumenpenelitian ini meliputi (1) instrument uji validitas, (2) angket respon guru dan siswa serta lembar observasi untuk melihat praktikalitas bahan ajar, serta (3) instrument tes hasil belajar dan lembar observasi aktivitas belajar siswa.

\section{Teknik Pengumpulan Data}

Pengumpulan data penelitian dilakukan dengan menggunakan teknik observasi dan tes.

\section{Teknik Analisis Data}

Data validasi dianalisis menggu-nakan statistik deskriptif (perhitung-an rata-rata hasil validasi pakar dan praktisi). Data praktikalitas dan uji efektifitas dianalisis menggunakan persentase rata-rata. 


\section{HASIL DAN PEMBAHASAN}

Model PBL merupakan salah satu model pembelajaran inovatif yang berangkat dari masalah dunia nyata siswa untuk belajar tentang cara berpikir kritis dalam memecahkan suatu permasalahan. Menurut Ronis (2001:7) "Problem based learning is based on the idea that individuals fashion their understanding largely throught what the experience". Pendapat Ronis tersebut jika diterjemahkan mengandung arti pembelajaran berbasis masalah didasarkan padagagasan bahwa individu bisa paham terutama melalui pengalaman.

Sejalan dengan itu, Bound and Feletti (dalam Barbara, 2001:6) "The basic principle supporting the concept of Problem Based Learning, is older than formal education it self, learning is initiated by a posed problem, query, or puzzle taht the learner want to solve". Pendapat Bound tersebut jika diterjemahkan mengandung arti bahwa prinsip dasar yang mendukung konsep dari Problem Based Learninglebih tua dari pendidikan formal itu sendiri. Belajar diprakarsai dengan adanya masalah, pertanyaan, atau permainan puzel yang akan diselesaikan oleh perserta didik itu sendiri.

Lebih lanjut, menurut Wena (2009:91) model Problem Based Learning merupakan strategi pembe-lajaran dengan menghadapkan siswa pada permasalahanpermasalahan praktis sebagai pijakan dalam belajar atau dengan kata lain siswa belajar melalui permasalahanpermasalahan. Sejalan dengan itu, Sanjaya (2009:214), model Problem Based Learning diartikan sebagai rangkaian aktivitas pembelajaran yang mene-kankan kepada proses penyelesaian masalah yang dihadapi secara ilmiah.

Pendapat ahli di atas, dapat disimpulkan bahwa model Problem Based Learning adalah suatu model pembelajaran yang menggunakan masalah dunia nyata sebagai langkah awal bagi siswa untuk belajar dalam mendapatkan pengetahuan dan konsep yang esensi dari setiap materi pembelajaran yang telah dimiliki siswa sebelumnya, sehingga terbentuklah pengetahuan yang baru.

Pelaksanaan Problem Based Learning merupakan suatu pendekatan pembelajaran yang dimulai dengan pemberian masalah nyata kepada siswa. Menurut Sanjaya (2009:214) mengemukakan, model Problem Based Learning diartikan sebagai rangkaian aktivitas pembelajaran yang menekankan kepada proses penyelesaian masalah yang dihadapi secara ilmiah. Sedangkan menurut Wena (2009:91) bahwa model Problem Based Learning merupakan strategi pembelajaran dengan menghadapkan siswa pada permasalahan praktis sebagai pijakan dalam belajar atau dengan kata lain peserta didik.

Hasil penelitian tentang pengembangan bahan IPA berbasis model Problem Based Learning untuk kelas V Sekolah Dasar dengan model pengembangan 4-D, diperoleh data hasil penelitian sebagai berikut:

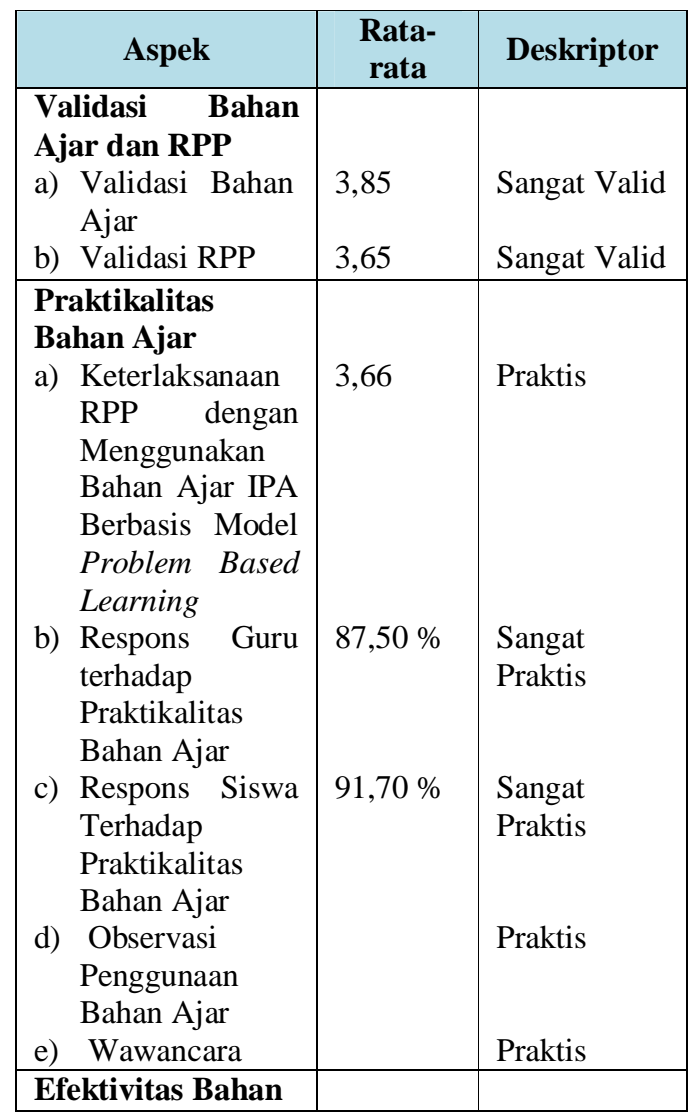




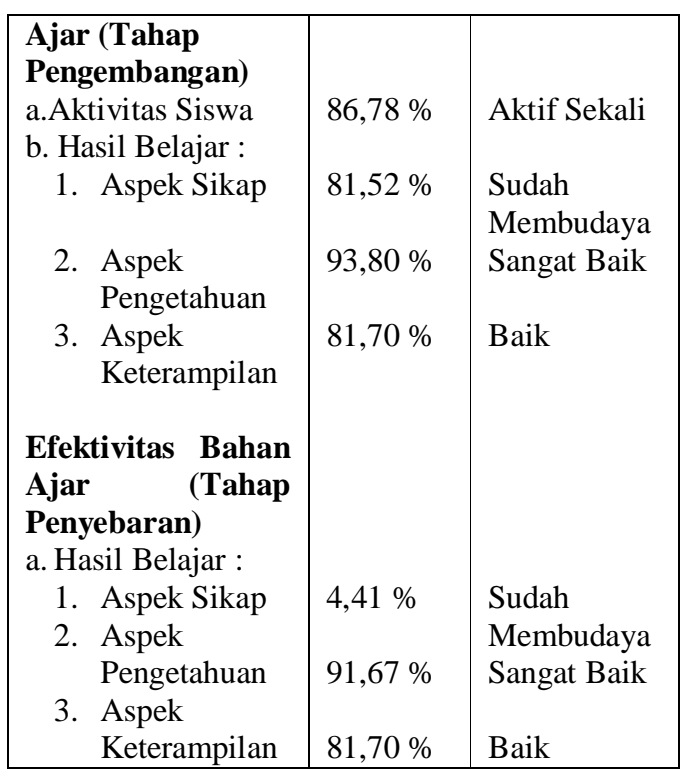

\section{PEMBAHASAN}

Produk yang dikembangkan dalam penelitian ini adalah Bahan Ajar IPA berbasis model Problem Based learning untuk kelas V SD. Produk tersebut telah diujicobakan pada siswa kelas V MIN Koto Luar Padang dan telah disebarkan pada siswa kelas V SDN 05 Sawahan dengan jumlah siswa 23 dan 31 orang. Paparan pembahasan mengenai hasil penelitian pengembangan yang telah dilakukan akan diuraikan lebih lanjut validitas, praktikalitas, dan efektivitas produk yang dikembangkan. Untuk lebih jelasnyapembahasan tersebut diuraikan sebagai berikut:

\section{Validasi Bahan Ajar dan RPP}

a. Validasi Bahan Ajar

Validasi bahan ajar dilakukan berdasarkan beberapa aspek yaitu aspek kelayakan isi, aspek kebahasaan, aspek penyajiandan aspek kegrafikaan. Hasil validasi ditinjau dari kelayakan isi memperoleh nilai rata-rata 3,90 dengan kategori sangat valid

b. Validasi Rencana Pelaksana-an Pembelajaran (RPP)

Rencana Pelaksanaan Pembelajaran (RPP) yang dirancang kemudian divalidasi oleh validator. Validasi dilaku-kan oleh tiga orang validator dari perguruan tinggi dan dua orang dari guru SD sama dengan validator bahan ajar. Pada kegiatan ini, pakar dan praktisi diminta untuk menilai RPP yang sudah dibuat.

Penilaian mencakup iden-titas, pemilihan kompetensi, perumusan indikator, pemilih-an materi pembelajaran, kegiatan pembelajaran pendekatan dan model pembelajaran, pemilihan sumber belajar, penilaian. Validator diminta untuk memberikan penilaian serta saran perbaikan dari RPP yang telah dirancang.

Hasil validasi RPP yang telah dilakukan oleh validator ahli dan ahli praktisi memperoleh nilai rata-rata 3,65 dengan kategori sangat valid.

\section{Praktikalitas Bahan Ajar}

a. Keterlaksanaan RPP dengan Menggunakan Bahan Ajar IPA Berbasis Model Probem Based Learning.

Berdasarkan hasil penga-matan terhadap keterlaksanaan RPP dengan menggunakan bahan ajar IPA berbasis model Problem Based Learningdi kelas VMIN Koto Luar Padang yang digunakan dalam uji coba berada dalam kriteria praktis dengan nilai rata-rata 3,66.

b. Respons Guru Terhadap Praktikalitas Bahan Ajar

Hasil analisis angket respon guru terhadap bahan ajar IPA berbasis model Problem Based Learning memperoleh rata-rata $87,50 \%$ dengan kategori praktis

c. Respons Siswa terhadap Praktikalitas Bahan Ajar

Hasil analisis angket respon siswa terhadap praktikalitas bahan ajar yang dikembangkan menunjukkan bahwa siswa tertarik mempelajari bahan ajar IPA berbasis model Problem Based Learningdengan jumlah rata-rata respon 91,70 dengan kategori sangat praktis 
d. Observasi Penggunaan Bahan Ajar dan Wawancara

Hasil Obeservasi bahan ajar kepada siswa dan wawacara kepada guru di sekolah Uji Coba MIN Koto Luar Padang menghasilkan Bahan ajar Model Problem Based Learning untuk kelas $\mathrm{V}$ ini praktis untuk digunakan

\section{KESIMPULAN}

Peneliti dapat menyimpulkan beberapa hal, sebagai berikut.

1. Bahan ajar Model Problem Based Learning yang dihasilkan pada penelitian pengembangan ini sangat valid dari segi isi yaitu 3,90 segi kebahasaan 3,80, segi penyajian 3,90 dan segi kegrafikan 3,80.

2. Bahan ajar Model Problem Based Learning yang dihasilkan pada penelitian pengembangan ini telah dapat dinyatakan sangat praktis dari hasil analisis respons guru yaitu dengan ratarata 87,50 dan aspek respons siswa dengan rata-rata 91,70.

3. Bahan ajar Model Problem Based Learning yang dihasilkan pada penelitian pengembangan ini telah dinyatakan efektif dilihat dari aktivitas dan hasil belajar. Aktivitas siswa dapat dilihat dari hasil pengamatan siswa pada saat uji coba dengan rata-rata 86,14 pada saat penyebaran menjadi 84,71 terdapat pada kategori sangat aktif. Hasil belajar siswa terdiri atas 3 aspek yaitu sikap, pengetahuan dan keterampilan. Pada aspek sikap saat uji coba diperoleh rata-rata keseluruhan 81,52 danpada saat penyebaran menjadi 84,41. Pada aspek pengetahuan saat ujicoba diperoleh persantase ketuntasan 93,80 dan pada saat penyebaran menjadi 91,67. Pada aspek keterampilan saat ujicoba diperoleh rata-rata 8,70 dan pada saat penyebaran 84,41 berada pada kategori baik.

\section{SARAN}

Saran tersebut adalah sebagai berikut:

1. Bagi pemerintah khususnya Dinas Pendidikan Kota Padang agar dapat mengadakan pelatihan bagi guru agar dapat mengem-bangkan bahan ajar yang sesuai dengan lingkungan siswa dan yang mampu mengembangkan keterampilan mengembangkan keterampilan pemecahkan masalah.

2. Untuk guru SD, berdasarkan hasil validitas, praktikalitas, dan efektifitas yang telah dilaksana-kan, bahan ajar IPA modelProblem Based Learning di kelas V sekolah dasar dapat sebaiknya digunakan sebagai salah satu alternatif dalam proses pembela-jaran materi gaya gravitasi, gaya gesek, dan gaya magnet.

3. Peneliti lain, dapat mengembang-kan bahan ajar IPA berbasis model Problem Based Learning pada materi lain dan ruang lingkup sekolah yang lebih luas dengan situasi dan kondisi yang berbeda untuk mendapatkan hasil yang lebih sempurna. Bahan ajar yang telah dikembangkan dapat dijadikan sebagai acuan dalam mengembangkan bahan ajar yang lain terutama yang berkaitan dengan pembelajaran di SD.

\section{DAFTAR PUSTAKA}

Asy'ari,Maslichah. (2006). Penerapan Pendekatan Sains - TekhnologiMasyarakat dalam Pembelajaran SAINS di Sekolah Dasar. Yogyakarta: Depdiknas

Barbara, J Duch \& Grob Susa, Susan E. (2001).The Power of Problem Based Learning. Jakarta: Prenata Media Group.

Daryanto dan Dwi Cahyono. (2014). Pengembangan Perangkat Pembelajaran. Jakarta: Gafa 
Permendiknas Nomor 16 Tahun 2007 tentang Standar Kualifikasi Akademik dan Kompetensi Guru.

Prastowo, Andi. (2011).Panduan Kreatif Membuat Bahan Ajar Inovatif Menciptakan Metode Pembelajaran yang Menyenangkan. Jakarta:Diva Press.

Rusman. (2012). Model-Model Pembelajaran. Jakarta: Raja Grafindo Persada.

Sagala, Syaiful. (2009). Kemampuan Profesional Guru dan Tenaga Kependidikan. Bandung:Alfabeta.

Sanjaya, Wina. (2009). Perencanaan dan Desain Sistem Pembelajaran. Jakarta: Prenada media Group.

-------. (2011). Strategi Pembelajaran Berorientasi Standar Proses Pendidikan. Jakarta: Kencana
Santrock, John W. (2007). Perkembangan Anak.Terjemahan oleh Mila Rachmawati dan Anna Kuswanti.. Jakarta : Erlangga

Sugiono.(2011). Metode Penelitian Pendidikan Pendekatan Kuantitatif, Kualitatif, dan $R \& D$. Bandung: Alfa Beta.

Thiagarajan, S., Semmel, D. S., and Semmel, M. L.. 1974. Instructional Development for Training Teachers of Exceptional Children: A Sourcebook. Minneapolis, Minnesota: USOE Publication.

Trianto. (2011). Mendisain Model Pembelajaran Inovatif-Progresif Tingkat Satuan Pendidikan. Jakarta: kencana Prenada Media Group.

Wena, Made. (2009). Strategi Pembelajaran Inovatif Kontemporer Suatu Tinjauan Konseptual Operasional. Jakarta: Bumi Aksara. 